\title{
REDUCTION OF CRANKSHAFT STRESS BY USING OF THE TORSIONAL VIBRATION DAMPER
}

\author{
MILATA Michal ${ }^{1}$, MUSIL Miloš ${ }^{2 *}$ \\ ${ }^{1}$ Slovak University of Technology in Bratislava, Faculty of Mechanical Engineering, Institute of Applied \\ Mechanics and Mechatronics, Nám. Slobody 17,812 31 Bratislava, Slovakia, e-mail: michal.milata@stuba.sk \\ ${ }^{2}$ Slovak University of Technology in Bratislava, Faculty of Mechanical Engineering, Institute of Applied \\ Mechanics and Mechatronics, Nám. Slobody 17,812 31 Bratislava, Slovakia, e-mail: milos.musil@stuba.sk
}

\begin{abstract}
This paper deals with the stress analysis of crankshaft of a 4- cylinder internal combustion engine. The crankshaft is during its operation subjected to static and dynamic load. High frequency dynamic cyclic loading can lead to material fatigue and eventually fracture. To reduce this dynamic loading a new type of torsional vibration damper built in the crankshaft counterweight will be analyzed with the use of numerical simulation. After defining boundary conditions and applying loads, Von Mises stress analysis will be performed using the finite element method.
\end{abstract}

KEYWORDS: crankshaft, torsional vibration, torsional vibration damper, internal combustion engine, Von Mises stress

\section{Introduction}

The crankshaft is one of the most critical components for the efficient and reliable operation of internal combustion engines. The development in the field of new internal combustion engines is aimed at increasing the engine power, engine torque, and higher engine cylinder pressure. All of these parameters increase the load of the crankshaft. Due to the application of forces transmitted through the connecting rod, the crank arm is in general position stressed on the transverse shear, bending, and twisting. The crankshaft is designed for two positions. The first position is for the maximum torque, and the second position is for the maximum bending moment. Considering the construction of the crank mechanism, and the way in which the torque is transmitted, torsional vibrations are of the highest intensity. They cause high frequency dynamic cyclic loading, which can lead to material fatigue and eventually fracture [1].

At the current level of crankshaft construction development, any attempt to avoid critical operational revolutions of the torsional vibration system, shifting the resonant crankshaft mode outside the operation revolutions, by changing the torsional stiffness or mass moments of inertia is quite unrealistic. The real way is the introduction of devices for the forced reduction of critical amplitudes of twist angle due to torsional vibrations, so-called torsional vibration dampers.

Torsional vibration dampers mounted on the front of the crankshaft are common methods for reducing dynamic loads. The most widely used torsional vibration dampers are viscoelastic. The disadvantages of these dampers are high price, low reliability, and increased weight of the crankshaft.

Recently, the development has focused on new types of dampers, which are already integrated into the existing components of the crankshaft. The advantage of such dampers is that they don't increase the total weight of the crankshaft, they are cheaper, and more reliable. However, at the same time, these dampers must effectively reduce the torsional vibrations of the crankshaft. Such dampers developing today are dampers built in the counterweights of the 
engine crankshaft. The damper is set within the crankshaft counterweight at the first joint on the side opposite to the engine's flywheel. The damper can be mounted in one or two balance weights, depending on the required inertial mass of the damper.
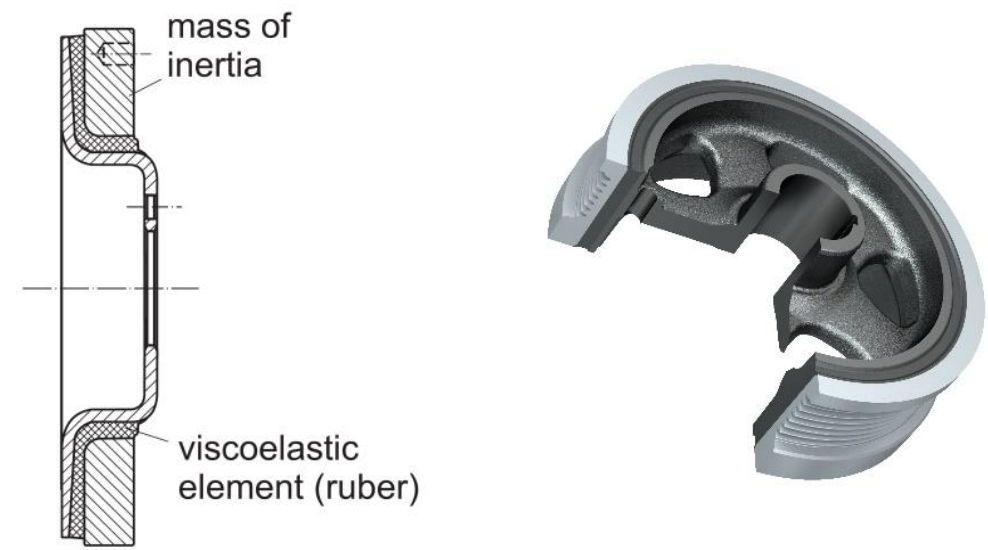

Fig. 1 Crankshaft viscous torsional vibration damper
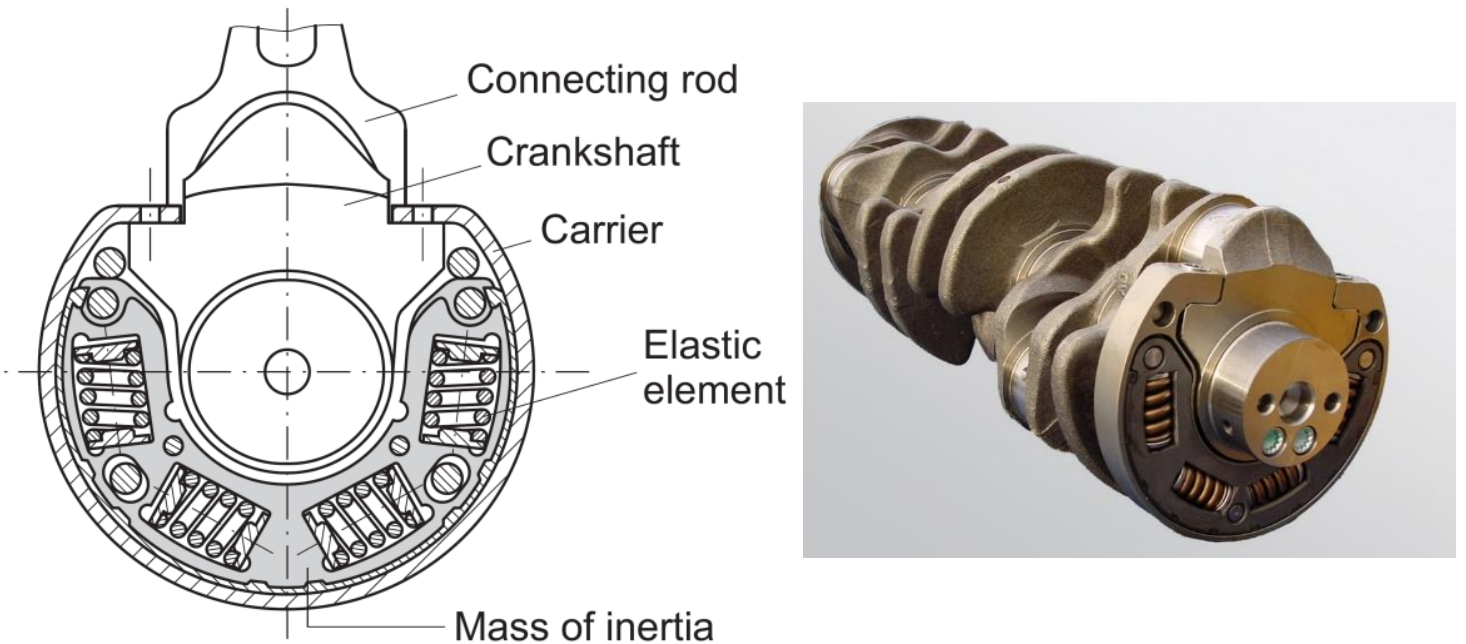

Fig. 2 Crankshaft counterweight built in torsional vibration damper

This paper gives a comparative analysis of the damping efficiency of the viscoelastic dampers and dynamic dampers built in the counterweights of the crankshaft. The analysis was done for a 4-cylinder internal combustion engine. Using MSC ADAMS for estimation of static and dynamic loads. The optimal parameters for the dynamic damper will be shown, and in the end the stress analysis of the crankshaft will be performed.

\section{Calculation of static loading forces}

During operation, the crankshaft is stressed in particular in the following ways:

- forces transmitted by individual connecting rods,

- inertia effects of bodies rotating with crankshaft,

- torsional, bending and longitudinal vibration forces and moments,

- forces caused by manufacturing inaccuracies and deformations of bearing supports or crankcase. 
Based on the previous simulations in the article [2], Fig. 3 shows the force from the gas pressure. This force is relatively constant and independent of crankshaft revolutions.

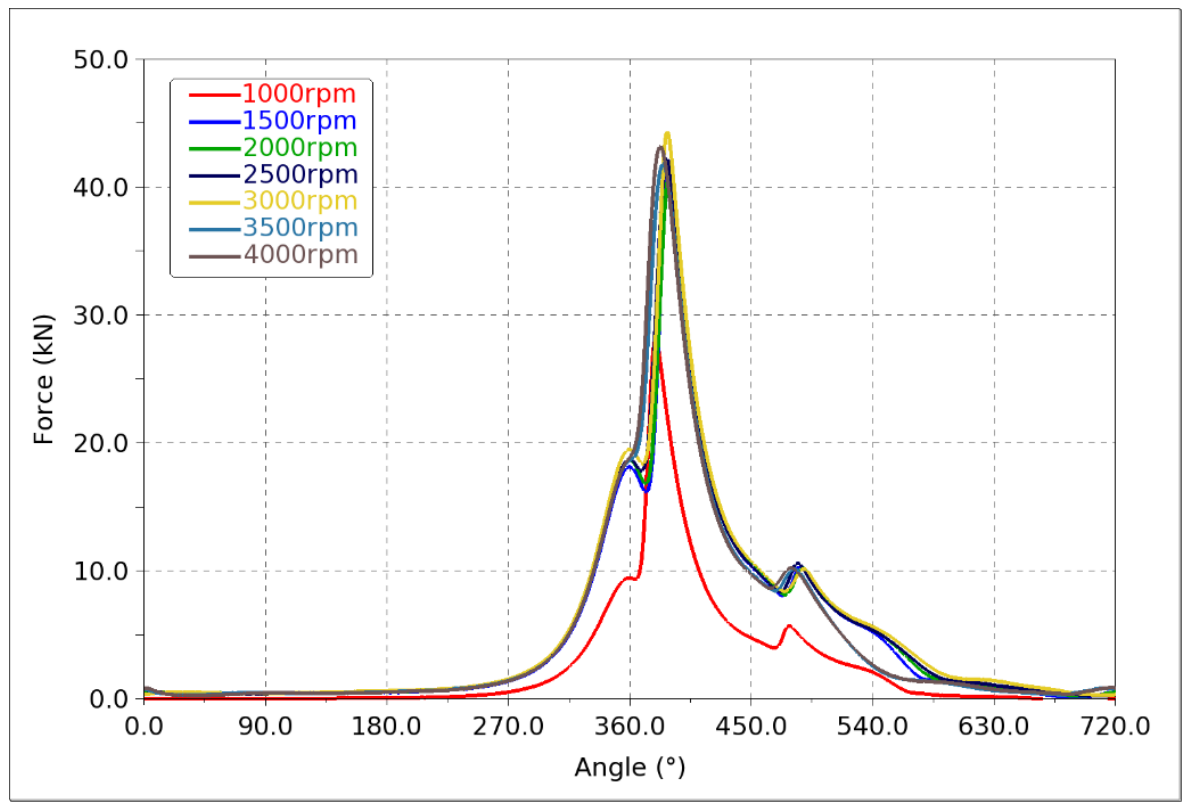

Fig. 3 Force transmitted by the connecting rod to the crankshaft

The radial component of the force transmitted through the connecting rod causes bending stress to the crankshaft, and the tangential component causes torsional stress. In Fig. 4, it can be seen that with increasing speed, the load on the crankshaft from the radial component decreases. It is because the force from the gas pressure is uniform throughout the operational speed range. The inertial force increases quadratically with increasing speed but acts in the opposite direction as the radial component of the force from the gas pressure, and thus these forces compensate each other.

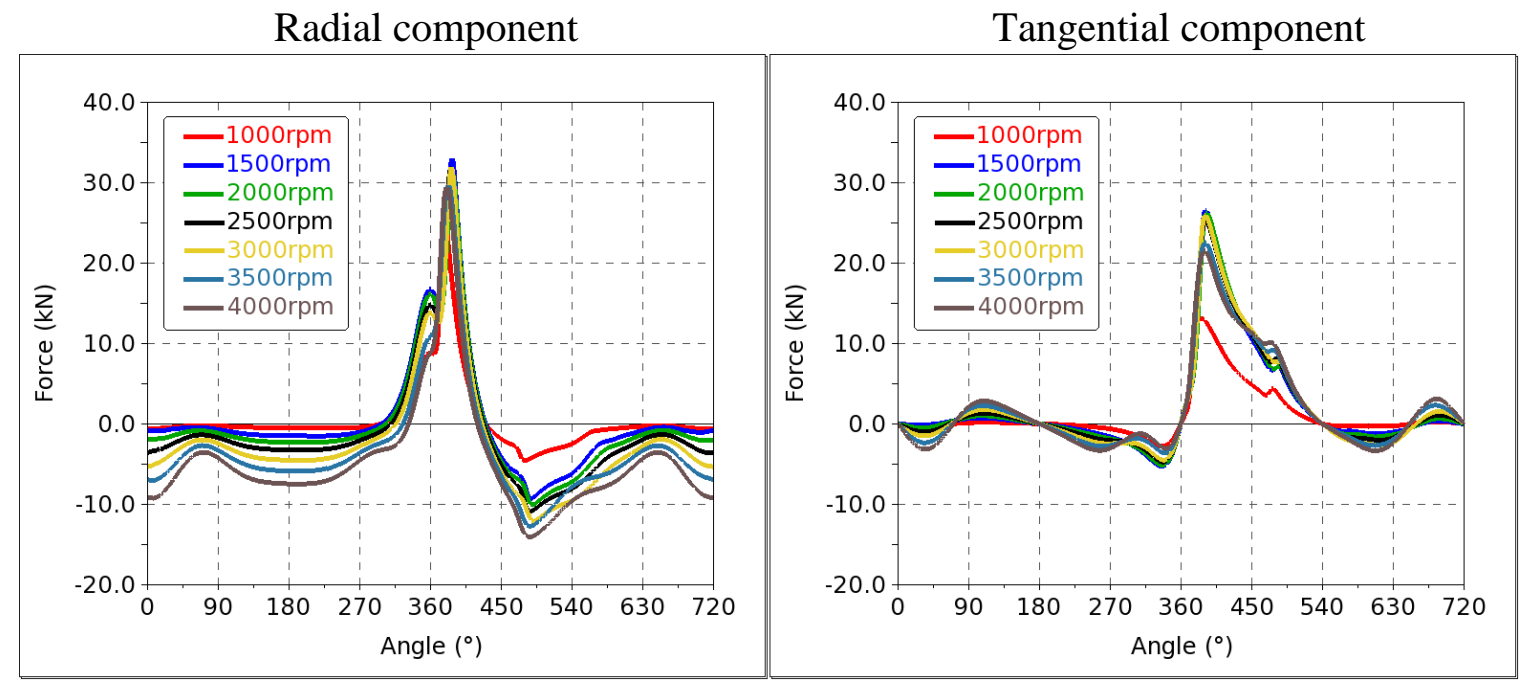

Fig. 4 Radial and tangential component of the force acting on the crankshaft

\section{Model of torsional vibration system}

With the dynamic stress analysis deals also author in article [3], but only for a singlecylinder crankshaft. When creating computational models to assess the dynamic stress due to torsional vibration, we can usually simplify the original system with continuously distributed 
parameters to the system with lumped parameters. Such a model of a crank mechanism is in Fig. 5.

a)

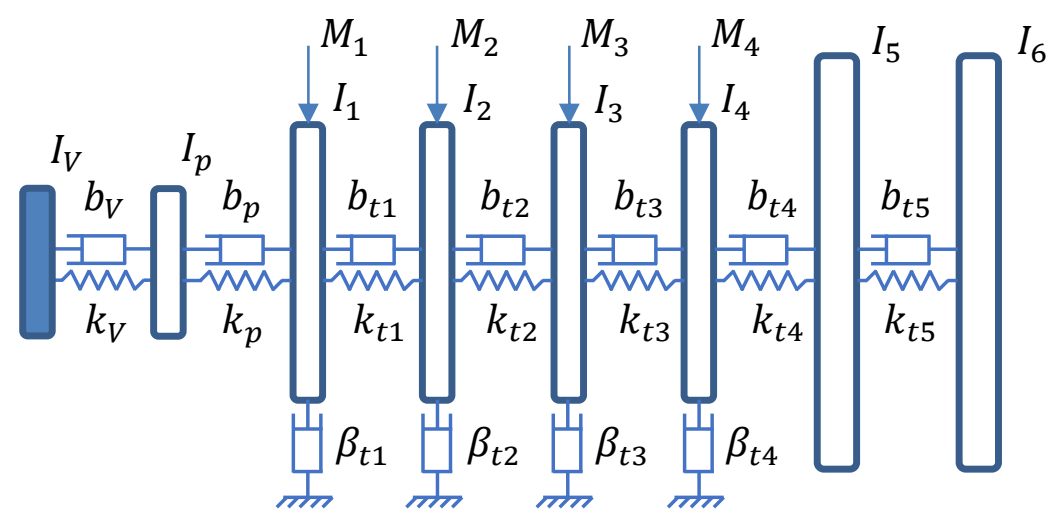

b)

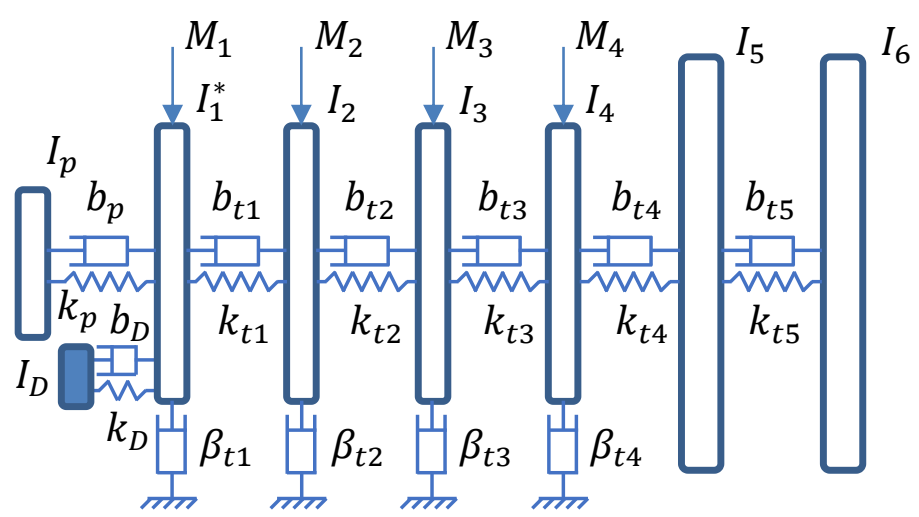

Fig. 5 The physical torsional vibration system model with a) viscoelastic and b) dynamic torsional vibration damper

The figure illustrates the concentrated masses of the dual- mass flywheel on the right side $I_{5}$, $I_{6}$, belt pulley on the left side $I_{p}$, viscoelastic damper $I_{V}$, and dynamic torsional damper $I_{D}$. The general equation of motion for the crank mechanism is

$$
\boldsymbol{M} \ddot{\boldsymbol{q}}(t)+\boldsymbol{B} \dot{\boldsymbol{q}}(t)+\boldsymbol{K} \boldsymbol{q}(t)=\boldsymbol{f}(t)
$$

Where the individual matrices without damper and pulley look as follows

$$
\begin{gathered}
\boldsymbol{M}=\left[\begin{array}{cccccc}
I_{1} & 0 & 0 & 0 & 0 & 0 \\
0 & I_{2} & 0 & 0 & 0 & 0 \\
0 & 0 & I_{3} & 0 & 0 & 0 \\
0 & 0 & 0 & I_{4} & 0 & 0 \\
0 & 0 & 0 & 0 & I_{5} & 0 \\
0 & 0 & 0 & 0 & 0 & I_{6}
\end{array}\right] \\
\boldsymbol{B}=\left[\begin{array}{cccccc}
b_{t 1}+\beta_{t 1} & -b_{t 1} & 0 & 0 & 0 & 0 \\
-b_{t 1} & b_{t 1}+b_{t 2}+\beta_{t 2} & -b_{t 2} & 0 & 0 & 0 \\
0 & -b_{t 2} & b_{t 2}+b_{t 3}+\beta_{t 3} & -b_{t 3} & 0 & 0 \\
0 & 0 & -b_{t 3} & b_{t 3}+b_{t 4}+\beta_{t 4} & -b_{t 4} & 0 \\
0 & 0 & 0 & -b_{t 4} & b_{t 4}+b_{t 5} & -b_{t 5} \\
0 & 0 & 0 & 0 & -b_{t 5} & b_{t 5}
\end{array}\right]
\end{gathered}
$$




$$
\begin{gathered}
\boldsymbol{K}=\left[\begin{array}{cccccc}
k_{t 1} & -k_{t 1} & 0 & 0 & 0 & 0 \\
-k_{t 1} & k_{t 1}+k_{t 2} & -k_{t 2} & 0 & 0 & 0 \\
0 & -k_{t 2} & k_{t 2}+k_{t 3} & -k_{t 3} & 0 & 0 \\
0 & 0 & -k_{t 3} & k_{t 3}+k_{t 4} & -k_{t 4} & 0 \\
0 & 0 & 0 & -k_{t 4} & k_{t 4}+k_{t 5} & -k_{t 5} \\
0 & 0 & 0 & 0 & -k_{t 5} & k_{t 5}
\end{array}\right] \\
\boldsymbol{q}=\left[\begin{array}{c}
\varphi_{1} \\
\varphi_{2} \\
\varphi_{3} \\
\varphi_{4} \\
\varphi_{5} \\
\varphi_{6}
\end{array}\right], \quad \boldsymbol{f}=\left[\begin{array}{c}
M_{1}(t) \\
M_{2}(t) \\
M_{3}(t) \\
M_{4}(t) \\
0 \\
0
\end{array}\right]
\end{gathered}
$$

The physical model of the torsional vibration system with a balance weight damper is shown in Fig. 5 b). It is necessary to modify the mathematical model described by the general equation (4), so it can be used for calculations with the balance weight damper. The vibration equations of mass $I_{1}$ as they are used in the conventional engine model Fig. 5 a)

$$
\begin{aligned}
I_{1} \ddot{\varphi}_{1}+\beta_{t 1} \dot{\varphi}_{1}+b_{p}\left(\dot{\varphi}_{1}-\dot{\varphi}_{p}\right)+b_{t 1}\left(\dot{\varphi}_{1}-\dot{\varphi}_{2}\right) & + \\
k_{p}\left(\varphi_{1}-\varphi_{p}\right)+k_{t 1}\left(\varphi_{1}-\varphi_{2}\right) & =M_{1}
\end{aligned}
$$

are replaced for the model with a balance weight damper Fig. 5 b) by two equations of the following form:

$$
\begin{gathered}
I_{1}^{*} \ddot{\varphi}_{1}+\beta_{t 1} \dot{\varphi}_{1}+b_{p}\left(\dot{\varphi}_{1}-\dot{\varphi}_{p}\right)+b_{t 1}\left(\dot{\varphi}_{1}-\dot{\varphi}_{2}\right)+b_{D}\left(\dot{\varphi}_{1}-\dot{\varphi}_{D}\right) \\
+k_{p}\left(\varphi_{1}-\varphi_{p}\right)+k_{t 1}\left(\varphi_{1}-\varphi_{2}\right)+k_{D}\left(\varphi_{1}-\varphi_{D}\right)=M_{1} \\
I_{D} \ddot{\varphi}_{D}+b_{D}\left(\dot{\varphi}_{D}-\dot{\varphi}_{1}\right)+k_{D}\left(\varphi_{D}-\varphi_{1}\right)=0
\end{gathered}
$$

The main condition to be fulfilled is the equality of mass moments of inertia of the disks $I_{1}=I_{1}^{*}+I_{D}$, so that the balance of inertial forces and corresponding moments of the complete engine can be maintained. This solution has fully eliminated the torsional vibration damper as a separate entity, and the balance weight damper should provide similar damping effects. The

\begin{tabular}{|c|c|c|c|c|c|}
\hline $\begin{array}{l}\text { Moment of } \\
\text { Inertia }\end{array}$ & $\left(\mathrm{kgm}^{2}\right)$ & $\begin{array}{l}\text { Torsional } \\
\text { stiffness }\end{array}$ & $\left(\mathrm{Nm} /{ }^{\circ}\right)$ & Damping & $\left(\mathrm{Nms} /{ }^{\circ}\right)$ \\
\hline$I_{p}$ & 0,00377 & $\boldsymbol{k}_{p}$ & 12094 & $b_{p}$ & 0,05 \\
\hline$I_{1}$ & 0,00507 & $k t_{1}$ & 4366 & $b t_{1}$ & 0,05 \\
\hline$I_{2}$ & 0,004673 & $k t_{2}$ & 4320 & $b t_{2}$ & 0,05 \\
\hline$I_{3}$ & 0,008813 & $k t_{3}$ & 4151 & $b t_{3}$ & 0,05 \\
\hline$I_{4}$ & 0,003899 & $k t_{4}$ & 5100 & $b t_{4}$ & 0,05 \\
\hline$I_{5}$ & 0,09059 & $k t_{5}$ & 30 & $b t_{5}$ & 0,05 \\
\hline$I_{6}$ & 0,353 & & & $\beta_{t 1}-\beta_{t 4}$ & 0,17 \\
\hline
\end{tabular}
basic parameters of the new damper are: moment of inertia of the damper $I_{D}$, torsional stiffness $k_{D}$ obtained from axial stiffness of springs distributed along the balance weight perimeter and internal damping defined by the internal damping coefficient $b_{D}$. The basic data of the model in Figure 5 are shown in Tab. 1 and

Tab. 2

Tab. 1 Dynamic parameters of crank mechanism 
Tab. 2 Mechanical parameters of crank mechanism

\begin{tabular}{|lc|}
\hline \multicolumn{1}{|c}{ Parameter } & Value \\
\hline Motor type & $R 4$ \\
\hline Firing order & $1-3-4-2$ \\
\hline Piston weight & $0,444 \mathrm{~kg}$ \\
\hline Conrod weight & $0,604 \mathrm{~kg}$ \\
\hline Rod length & $144 \mathrm{~mm}$ \\
\hline Crank arm & $46,4 \mathrm{~mm}$ \\
\hline
\end{tabular}

Torsional stiffness of the system $k_{t 1}$ to $k_{t 5}$ was determined using the finite element method. The crankshaft was divided into individual parts, which are located between bodies with a reduced moment of inertia $I_{1}$ to $I_{5}$. The torsional stiffness was measured based on the twist angle that results from the specified torque. Fig. 6 shows the results of simulations for measuring the torsional stiffness of individual parts of the crankshaft.

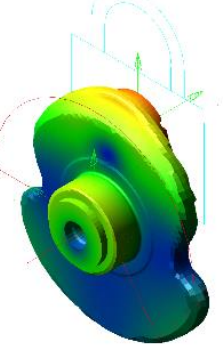

$k_{p}$

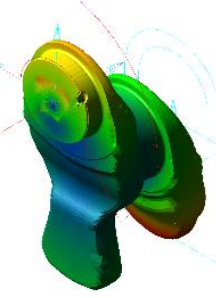

$k_{t 1}$

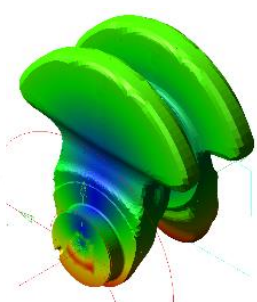

$k_{t 2}$

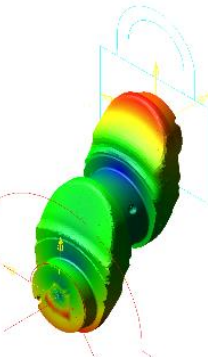

$k_{t 3}$

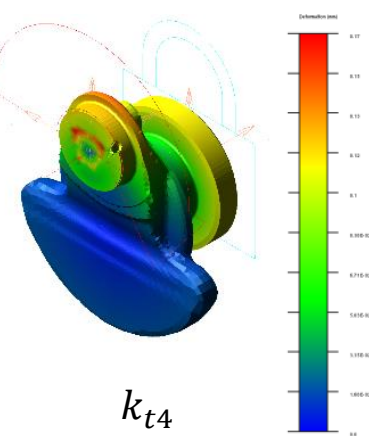

$k_{t 4}$

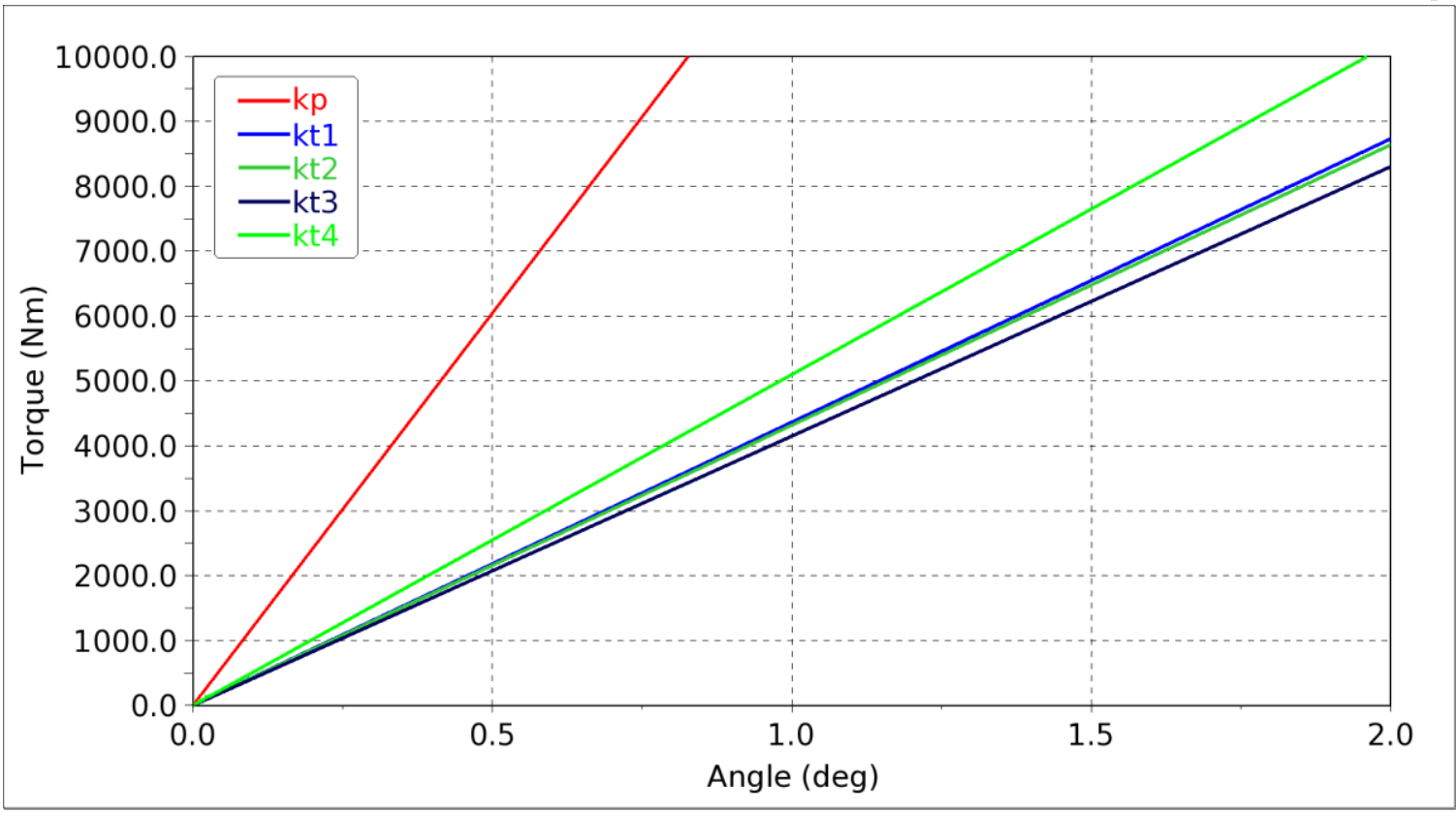

Fig. 6 Simulation of torsional stiffness of individual parts of the crankshaft

Moments of inertia of individual parts of the crank mechanism were determined from the CAD model. Moment of inertia $I_{6}$ represents the total reduced moment of inertia of the drive system driven by the crank mechanism. One of the most critical parameters for the frequency response calculation is the estimation of damping properties. In the paper [4], the measurement 
of frequency response function (FRFs) is performed, to show the damping properties of the simplified model.

\section{Eigenfrequencies and eigenvectors}

Analysis of eigenfrequencies and eigenvectors is one of the first steps in the torsional stress evaluation. When we know the eigenfrequencies, we can determine the critical operating rotational speed of the mechanism. With eigenvectors, we can determine the shape of the oscillation under which the system is stressed, and we can determine the places with maximum torsion. The equations of motion for the undamped torsion system have the following form in the matrix notation

$$
\boldsymbol{M} \ddot{\boldsymbol{q}}(t)+\boldsymbol{K} \boldsymbol{q}(t)=\mathbf{0}, \quad \boldsymbol{q}(0)=\boldsymbol{q}_{z}, \quad \dot{\boldsymbol{q}}(0)=\dot{\boldsymbol{q}}_{z}
$$

From a mathematical point of view, it is a homogeneous system of linear differential equations with constant coefficients, which has a solution in the following form

$$
\boldsymbol{q}(t)=\boldsymbol{v} e^{i \omega_{0} t}
$$

With unknown vector $\boldsymbol{v}$ and constant $\omega_{0}$. Implementing the solution Chyba! Nenašiel sa žiaden zdroj odkazov. into the equation Chyba! Nenašiel sa žiaden zdroj odkazov. we get a system of homogeneous algebraic equations whose solution leads to the eigenvalue problem

$$
\left(\boldsymbol{K}-\omega_{0}^{2} \boldsymbol{M}\right) \boldsymbol{v}=\mathbf{0}
$$

From the condition of nonzero solution

$$
\operatorname{det}\left(\boldsymbol{K}-\omega_{0}^{2} \boldsymbol{M}\right)=0
$$

follows $n$ eigenvalues $\lambda_{j}=\omega_{0 j}^{2}$ and $n$ eigenvectors $v_{j}(j=1,2, \ldots, n)$.

The 1. and 2. eigenvector of the torsional system shows the Fig. 7.
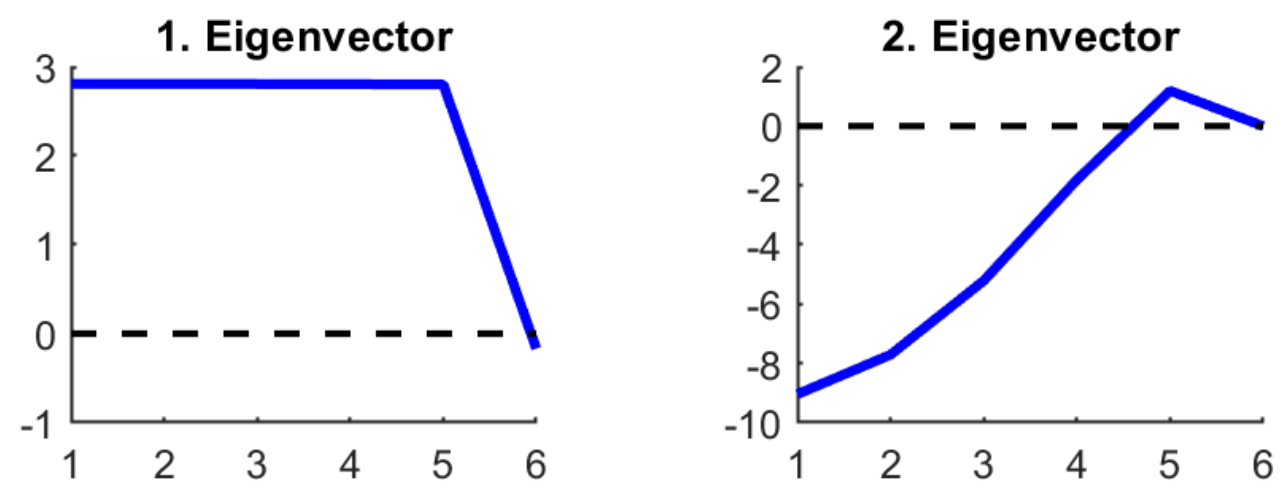

Fig. 7 Eigenvectors of the torsional system

The 1. and 2. eigenmode is plotted into the Campbell diagram of the 4- cylinder internal combustion engine in the Fig. 8. The torsional system has its 1 . eigenmode at $16 \mathrm{~Hz}$ and 2 . eigenmode at $429 \mathrm{~Hz}$ range. The 2 . eigenmode contributes to a significant increase in the dynamic stress of the crankshaft. It is necessary to design a broadband torsional vibration damper to suppress torsional vibration. In practice, such a damper is attached to the front of the crankshaft, where are the biggest torsional amplitudes. 


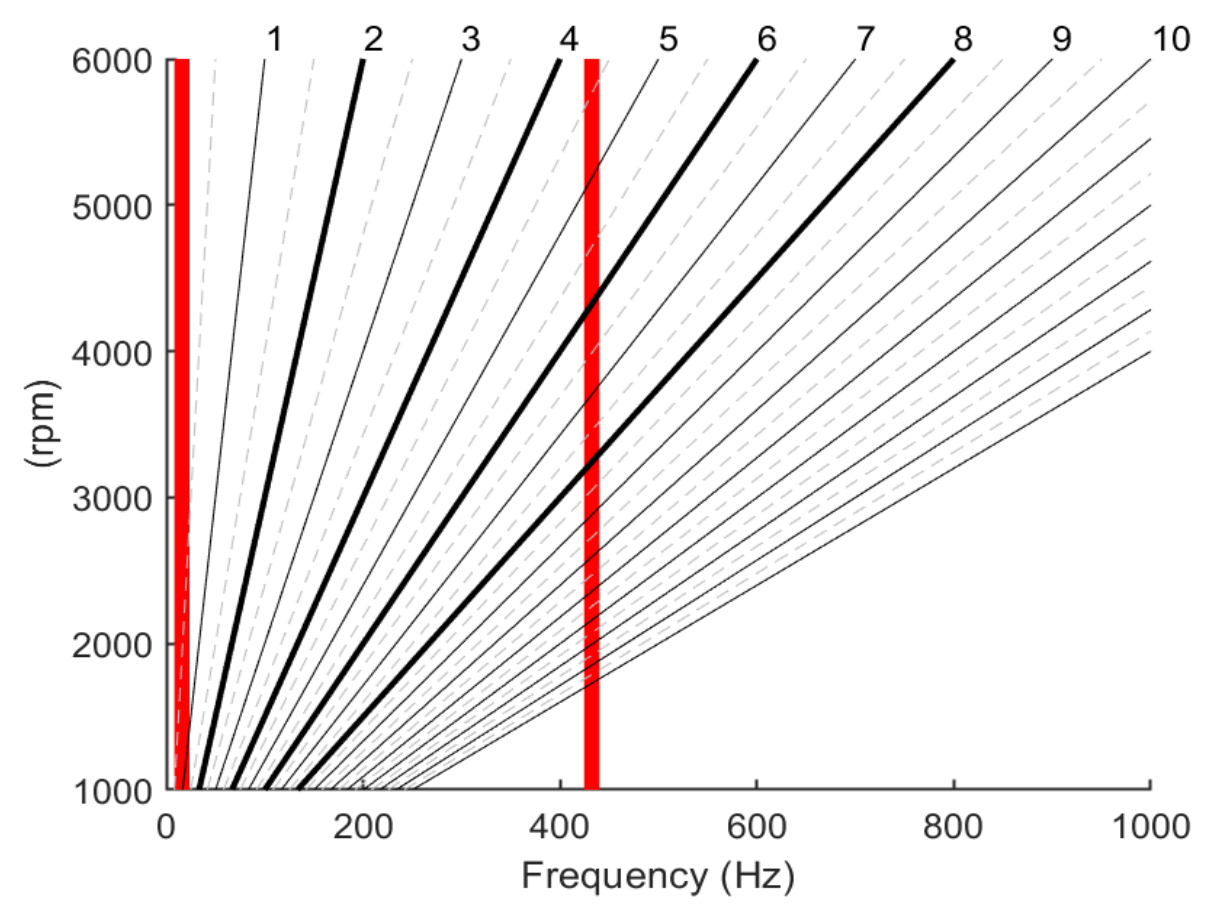

Fig. 8 Campbell diagram

An engine measurement was performed to verify the results obtained by the calculation. Experimental setup for measurement of torsional vibration on crankshaft shows Fig. 9. The angular amplitudes of the torsional vibrations at the front end of the crankshaft was measured using a laser. The crankshaft had no torsional vibration damper during the measurement. The frequency spectrum in the range $0-1000 \mathrm{~Hz}$ shows Fig. 10. The motor was accelerated under full load in the $3 \mathrm{rd}$ gear in the entire operating speed range from 1000 to $6000 \mathrm{rpm}$. The z-axis shows the angular amplitude of the torsional oscillation of the crankshaft in degrees. The diagram clearly shows the significant harmonic components of excitation 2, 4, 6, and 8th order. The main harmonic order of a 4-cylinder engine is the 2 . harmonic. Furthermore, it is possible to see a significant increase in the application of torsional oscillations in the frequency range $400-450 \mathrm{~Hz}$. The largest amplitudes were measured at the cross-section of 6th and 8th harmonic components with the 2 . eigenmode.

\section{Calculation of dynamic loading forces}

In the case of linear torsion systems with constant parameters, a steady deflection is possible $\varphi_{j}(t)$ based on the principle of superposition as a sum of responses to the individual harmonic components of excitation $\omega_{\kappa}=\kappa \omega$, where $\kappa$ is the multiple of the shaft rotational speed. In the case of piston machines, the excitation has the character of a periodic function that can be developed into a Fourier series. In case of periodic excitation torque $M_{k}(t)$ with amplitudes $\kappa$ $\left(M_{C k \kappa}, M_{S k \kappa}\right)$ follows

$$
M_{k}(t)=\sum_{\kappa=0}^{\infty} M_{C \kappa} \cos \left(\omega_{\kappa}(t)\right)+M_{S \kappa} \sin \left(\omega_{\kappa}(t)\right)
$$

The equations of motion can be expressed in a matrix form

$$
\boldsymbol{M} \ddot{\boldsymbol{q}}(t)+\boldsymbol{B} \dot{\boldsymbol{q}}(t)+\boldsymbol{K} \boldsymbol{q}(t)=\sum_{\kappa=0}^{\infty} \boldsymbol{f}_{0 \kappa} e^{i \omega_{\kappa} t}
$$




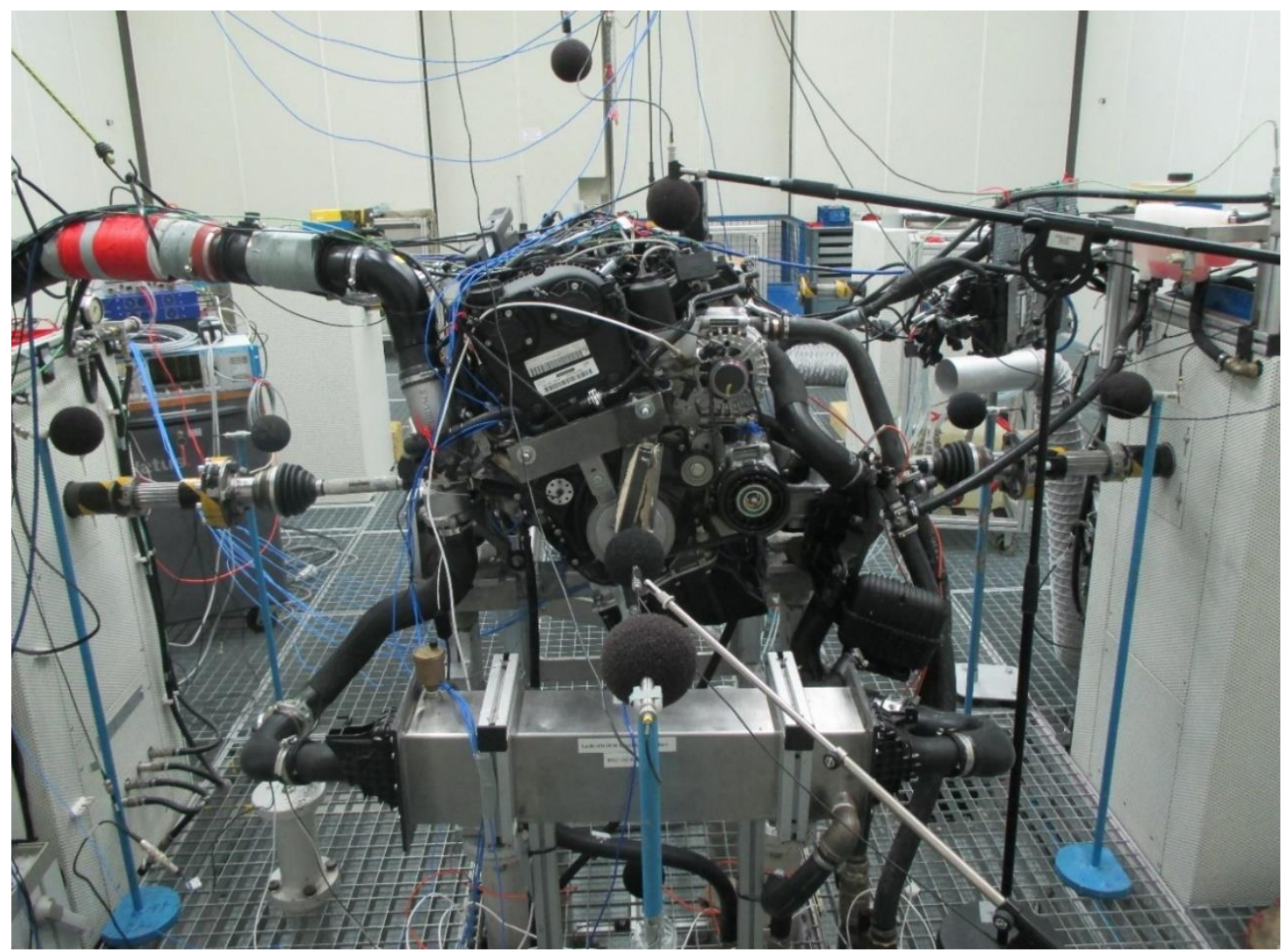

Fig. 9 Experimental setup for measurement of torsional vibration on crankshaft

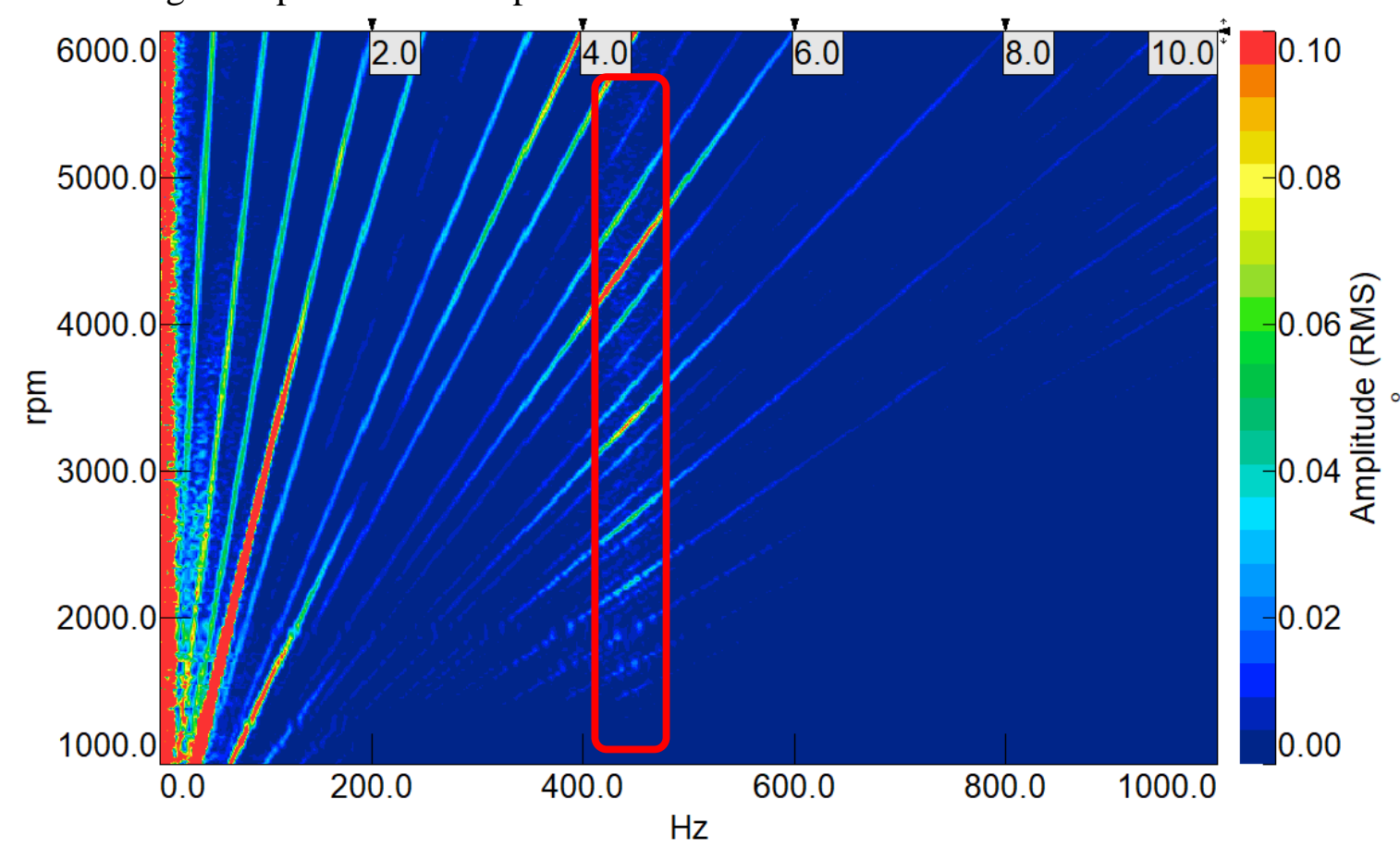

Frequency

Fig. 10 Campbell diagram for torsional vibration on crankshaft

where for a vector of complex amplitudes of order $\kappa$ harmonic component follows

$$
\boldsymbol{q}_{0 \kappa}=\left(\boldsymbol{K}+i \omega_{\kappa} \boldsymbol{B}-\omega_{\kappa}^{2} \boldsymbol{M}\right)^{-1} \boldsymbol{f}_{0 \kappa}=\boldsymbol{q}_{C \kappa}-\boldsymbol{q}_{S \kappa}=\boldsymbol{q}_{M \kappa} e^{-i \boldsymbol{\psi}_{\kappa}}
$$


and for the steady-state vector $\boldsymbol{q}(t)$ follows:

$$
\boldsymbol{q}(t)=\sum_{\kappa=0}^{\infty} \boldsymbol{q}_{C \kappa} \cos \left(\omega_{\kappa} t\right)+\boldsymbol{q}_{S \kappa} \sin \left(\omega_{\kappa} t\right)=\sum_{\kappa=0}^{\infty} \boldsymbol{q}_{M \kappa} \cos \left(\omega_{\kappa} t-\boldsymbol{\psi}_{\kappa}\right)
$$

The amplitude-frequency response of the system can be determined using the Kramer rule

$$
q_{0 j \kappa}=\left(\frac{\Delta_{j \kappa}}{\Delta_{\kappa}}\right), \quad \Delta=\operatorname{det}\left(\boldsymbol{K}+i \omega_{\kappa} \boldsymbol{B}+\omega_{\kappa}^{2} \boldsymbol{M}\right)
$$

Due to the different phase shifts of the individual harmonic components, the maximum steadystate displacement can be determined $\boldsymbol{q}_{M}$ using effective estimation $\boldsymbol{q}_{M E}$

$$
\boldsymbol{q}_{M E}=\boldsymbol{q}_{C 0}+\sqrt{\left(\sum_{\kappa=0}^{\infty} \boldsymbol{q}_{C \kappa}^{2}+\boldsymbol{q}_{S \kappa}^{2}\right)}
$$

To achieve the best possible results, for future analysis, a simulation model in software MSC ADAMS was built, and the analysis was done with ADAMS Vibration Plugin. The model shows Fig. 11. The crankshaft is in the model as a flexible body with its full elasticity. All other parts in the model are rigid bodies described with mass, center of gravity, and inertia parameters.

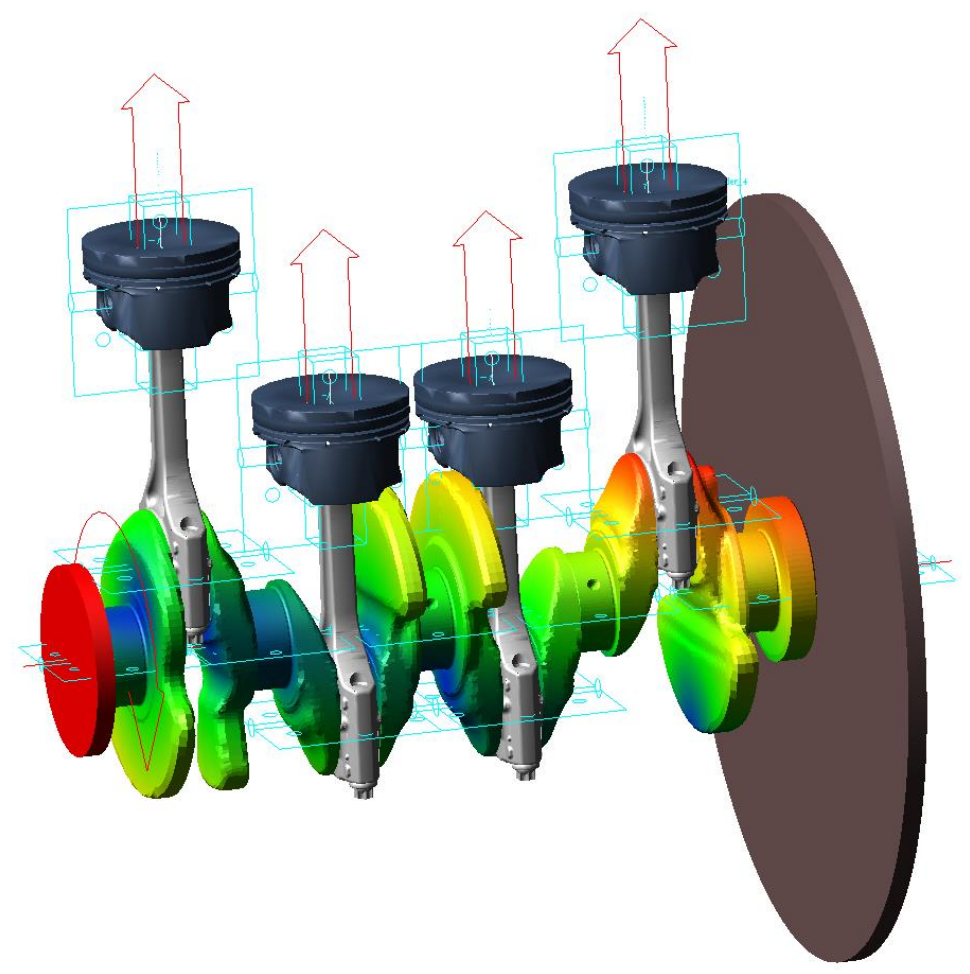

Fig. 11 Simulation model of the crank mechanism

To find the optimal dynamic damper parameters was used the ADAMS Vibration function with the name Design of Study. All of the damper parameter was modified in a realistic and meaningful range. The mass moment of inertia $I_{D}$ was modified in the range of $0,001-$ $0,003\left(\mathrm{kgm}^{2}\right)$. The dynamic torsional stiffness parameter $k_{D}$ was modified in the range of $50-1500\left(\mathrm{Nm} /{ }^{\circ}\right)$. And finally, the damping parameter $b_{D}$ was modified in the range of 
$\left.0,001-0,5\left(\mathrm{Nms}^{\circ}\right)^{\circ}\right)$. The results for the optimal damper parameters $I_{D_{\text {opt }}}, k_{D_{\text {opt }}}$ and $b_{D_{\text {opt }}}$ shows the following Fig. 12.

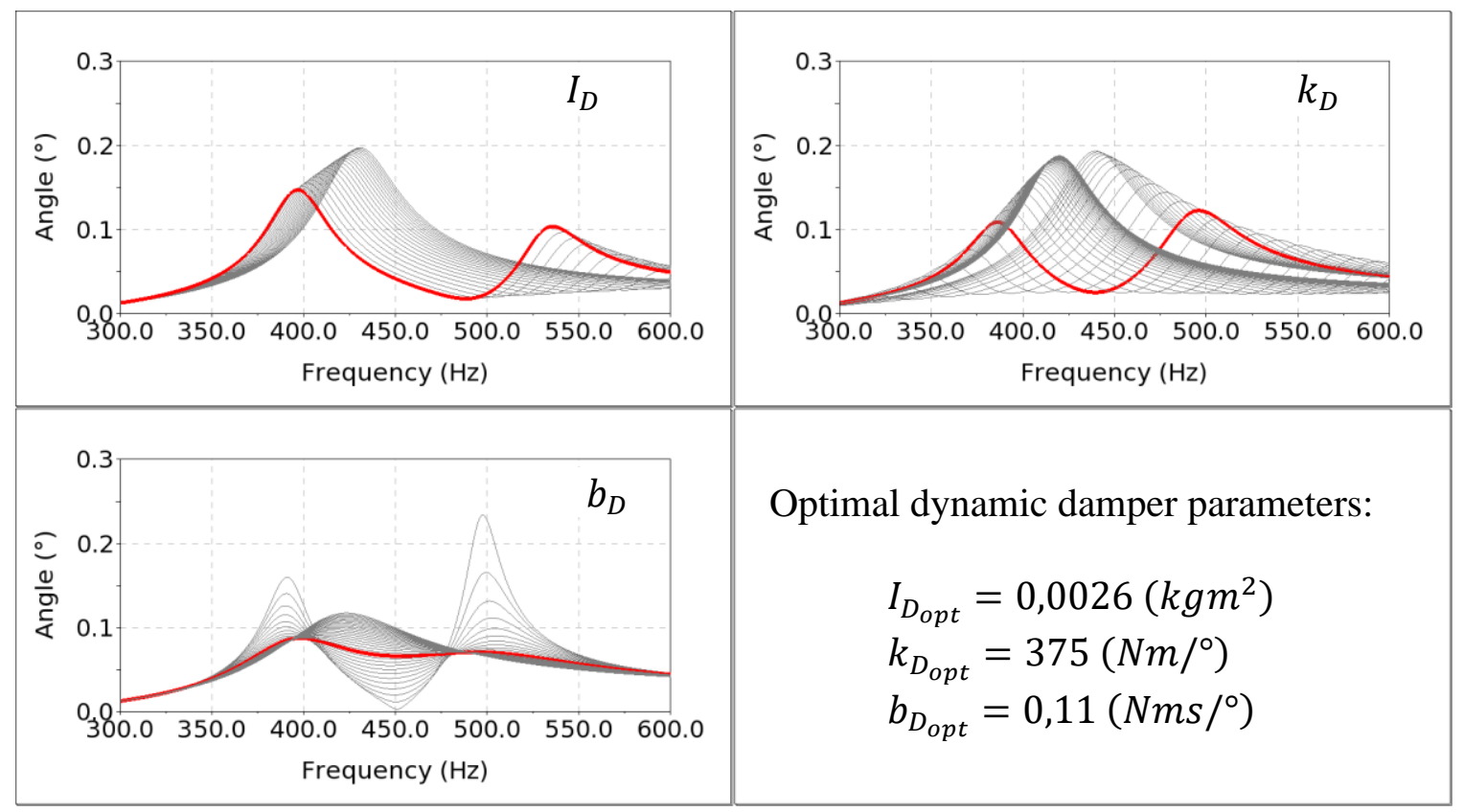

Fig. 12 Design of study for optimal damper parameters

The frequency response of the model for twist angle at the engine pully in 2, 4, 6, and 8th harmonic order of engine excitation is shown in Fig. 13. The model shows a good correlation with measured data on the engine without damper. Dynamic damper with optimal parameters shows good performance and can fully replace the viscoelastic damper.

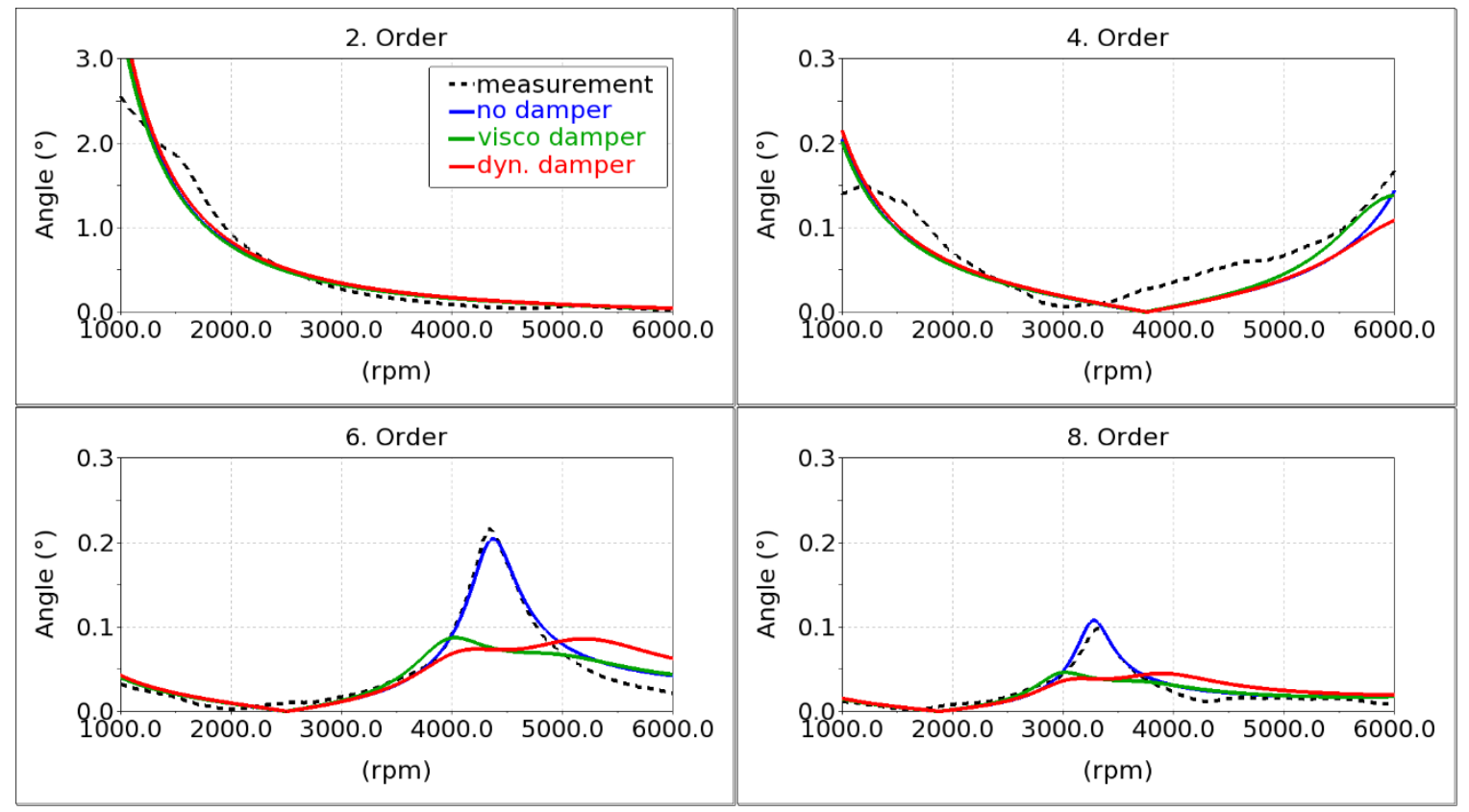

Fig. 13 Twist angle amplitude on the engine pulley 
Similar results can be seen in Fig. 14 for the torque amplitude in crankshaft on the side of the flywheel. It can be seen that in the area of reaching a maximum speed of $6000 \mathrm{rpm}$, the system enters resonance with 4 . harmonic order and at the area of $4500 \mathrm{rmp}$ with 6 . harmonic order and is subjected to a relatively large dynamic load, which is almost up to twice the maximum torque produced by the internal combustion engine.

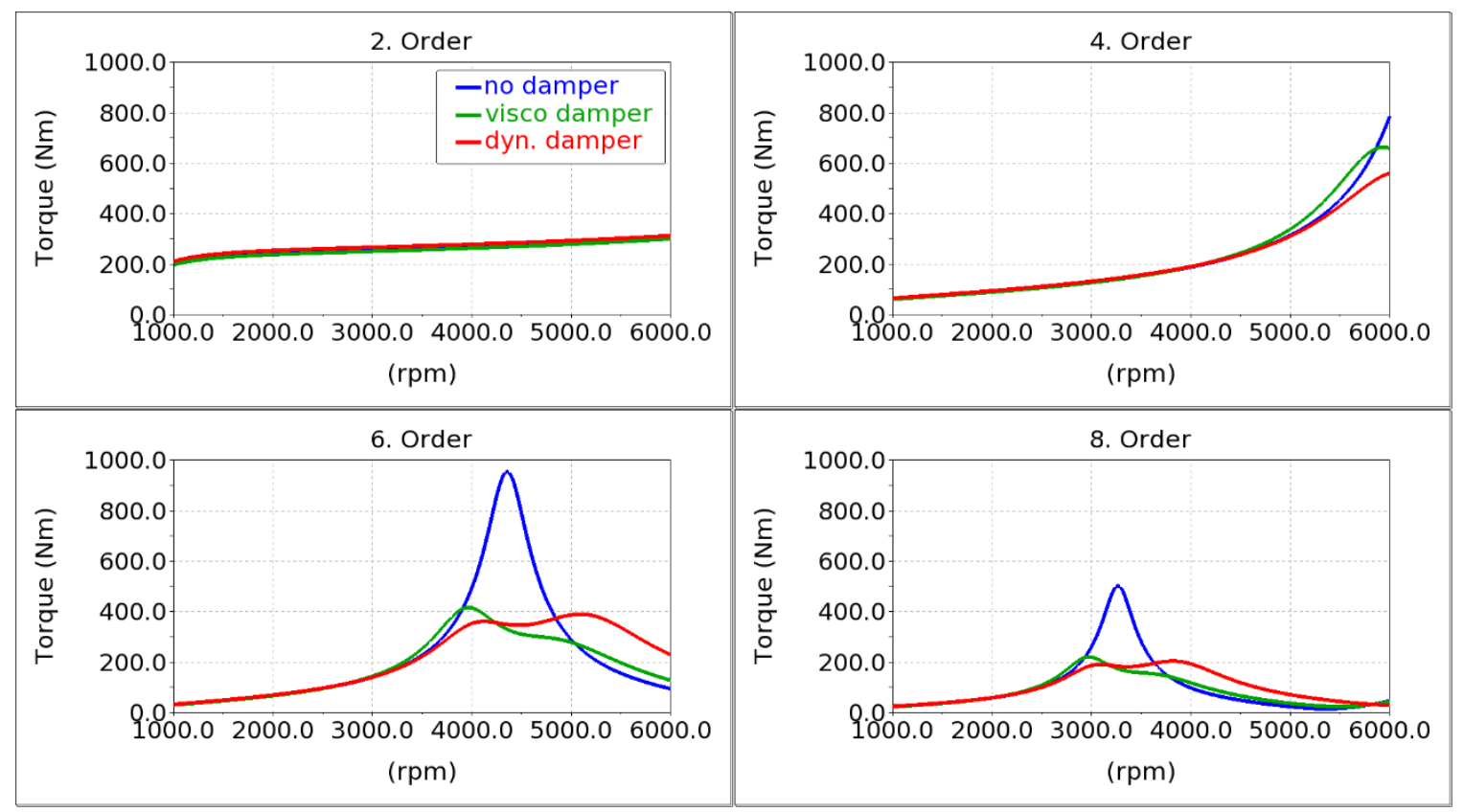

Fig. 14 Torque amplitude at the side of the flywheel

\section{Von Mises stress analysis}

Since the crankshaft has a relatively complicated geometry, the finite element method was used to calculate the surface stress. The author in the article [5] uses also von Mises stress analysis for the simulation of a high precision positioning system. The meshed crankshaft geometry shows Fig. 15. The solid element CHEXA, was used for the meshing. The model shown had 462,676 nodal points and 415,930 elements. The shaft material was steel with the modulus of elasticity $E=210 \mathrm{GPa}$, with Poisson's constant $\mu=0,3$ and density $7850 \mathrm{kgm}^{3}$ [6]. The total weight of the shaft in the simulation model was $13.0435 \mathrm{~kg}$. The boundary conditions that were used in the simulation are shown in blue color in Fig. 15. On the right side, at the flywheel mounting point, the crankshaft was fixed, and 2 degrees of freedom were left at all other locations where the crankshaft is mounted in bearings. The first degree of freedom is the rotation about the longitudinal axis of the shaft. The second degree of freedom is the displacement in the direction of the axis of rotation. Other degrees of freedom were removed. At the place of the connecting rod number 1, the crankshaft was loaded with a combination of tangential force $F_{t}$, which causes torsional stress and radial force $F_{r}$, which causes bending stress. The magnitude of the loading forces was determined based on, simulations according to Fig. 4. The crankshaft was also loaded with torque caused by torsional vibration. The torque was determined based on simulations in Fig. 14. 


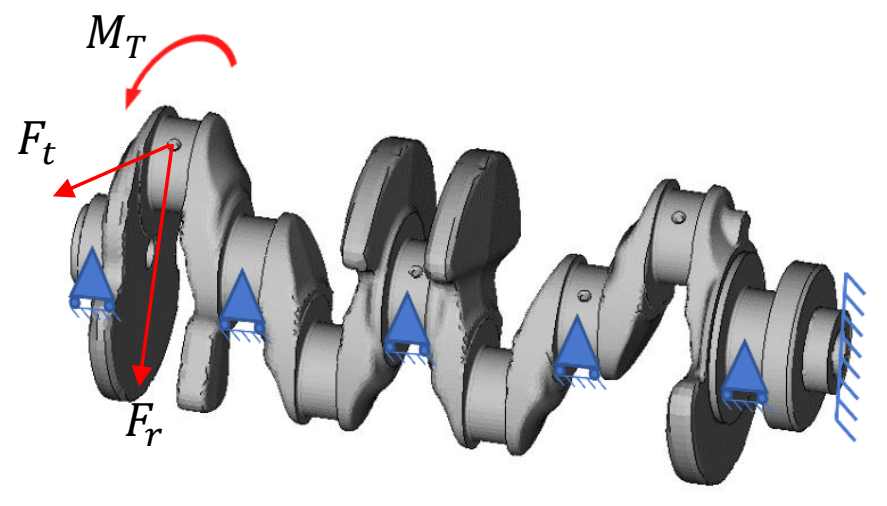

Fig. 15 Crankshaft boundary conditions

The results of the Von Mises stress analysis shows Fig. 16. Based on the simulation result is most stressed the right-hand part of the crankshaft in the flywheel mounting area. The shaft load in this section is within the range of 200 to $240 \mathrm{MPa}$.
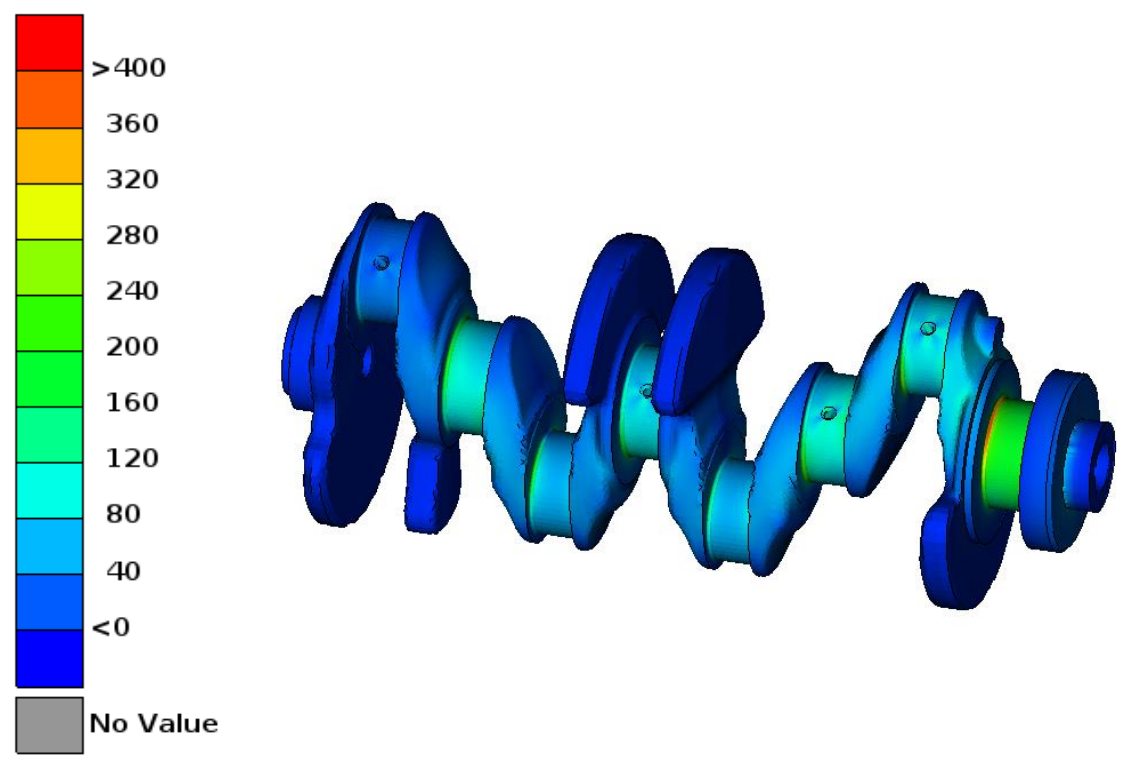

Fig. 16 Von Mises stress analysis

However, due to the geometry of the crankshaft, there are also areas with higher stresses. Especially in the notch region, where the stress reaches almost $400 \mathrm{MPa}$, and in the region of the edge of the oil canal, where the tension reaches almost $360 \mathrm{MPa}$. 

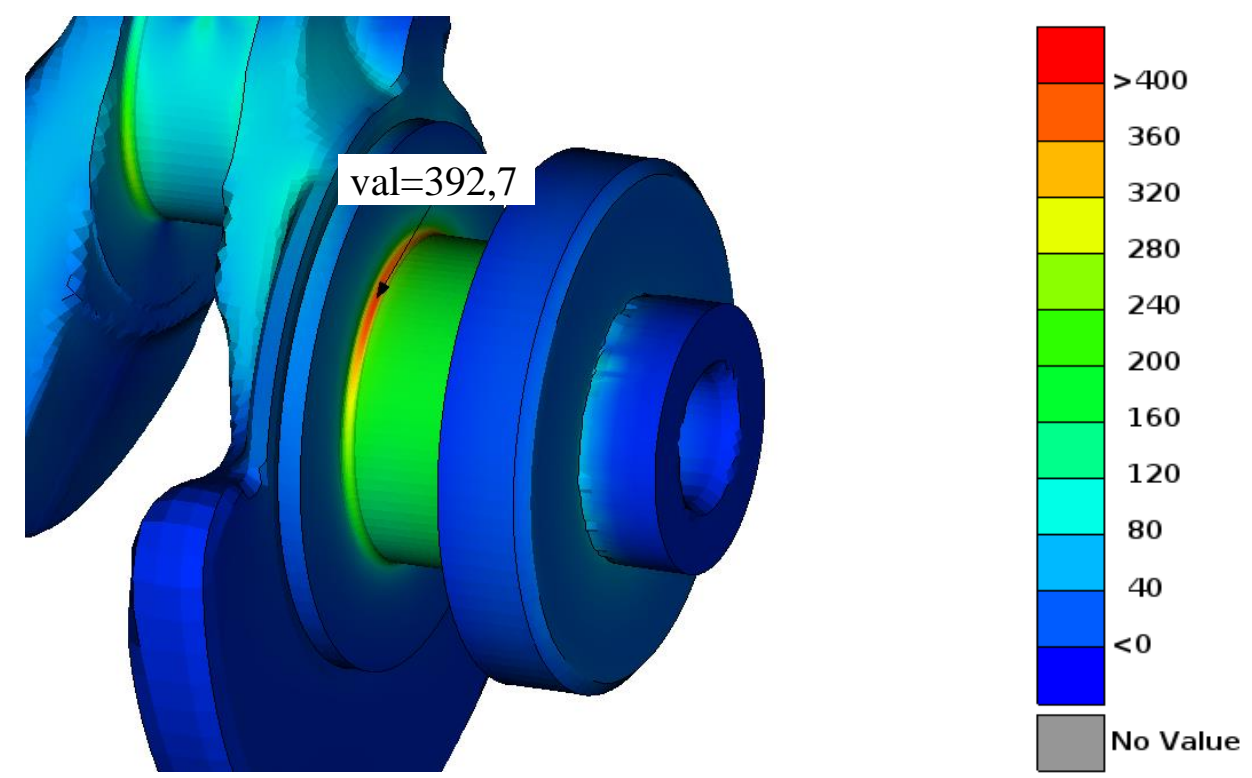

Fig. 17 Max. tension on the crankshaft in the notch area
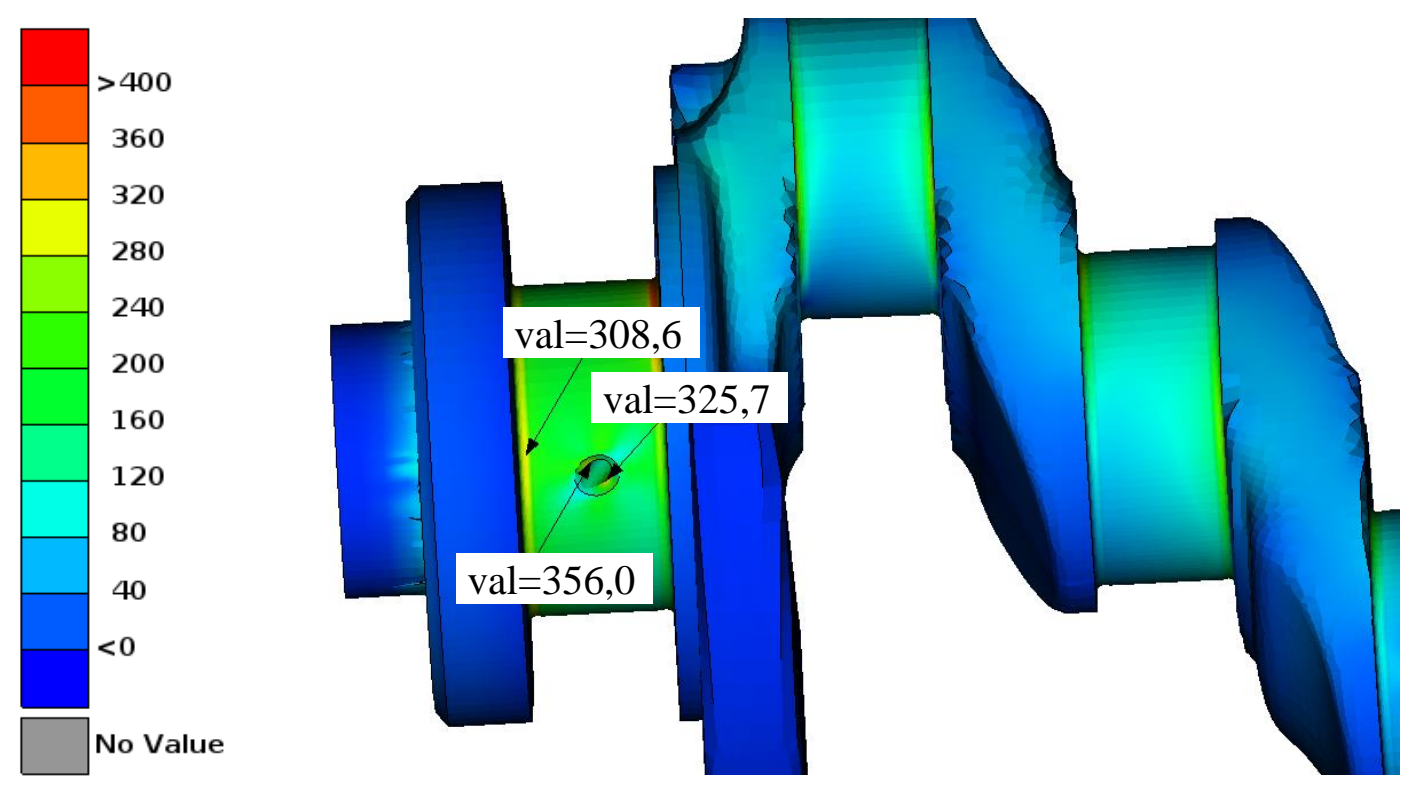

Fig. 18 Max. tension on the crankshaft in the region of the oil canal edge

\section{Conclusion}

Through the analysis of a torsional vibration system of an internal combustion engine with two different torsional vibration dampers it can be concluded:

- The same or even better damping effects of amplitudes of crankshaft twist angel due to torsional vibration can be obtained by incorporating a dynamic damper in the crankshaft counterweight instead of using conventional viscoelastic dampers.

- The engine eigenmode doesn't change with using the dynamic torsional vibration damper about the eigenmode of the engine without a torsional vibration damper. Also, conventional viscoelastic torsional vibration dampers significantly reduce the value of the resonant crankshaft speed relative to the eigenmode of the crankshaft without the damper. 
- Bearing in mind the real design and dimensions of the crankshaft with counterweights for medium-speed engines for road vehicles, there is enough space for incorporating a dynamic torsional vibration damper, with an optimum moment of inertia of the inertial mass and stiffness of the spring damper, into one counterweight.

The crankshafts of less stressed machines are made of structural or tempered carbon steels with a tensile strength of 500 to $700 \mathrm{MPa}$. For high-loaded shafts, heat-treated steel with a tensile strength above $1000 \mathrm{MPa}$ is used. The cast shafts are made of gray, alloyed, vaccinated, ductile, or tempered cast iron. Stainless steels (according to STN 420074 and 420075 classified in grades 12 to 16) are steels intended for heat treatment. The resulting properties of the steels thus depend on the heat treatment method. Steels of grade 12 have no alloying content higher than $1 \%$. Steels of grades 13 to 16 have an alloying content of up to $6 \%$. Therefore, they are sometimes referred to as standard alloys. The main alloying elements are manganese, silicon, chromium, molybdenum, vanadium, and nickel. The primary type of heat treatment of stainless steels is refining (hardening with subsequent tempering at high temperatures). This group also includes steels for cementation and nitriding. The mechanical properties of such steel are yield strength $R_{e}=235$ to $1570 \mathrm{MPa}$ (depending on the heat treatment method) and strength $R_{m}=$ 441 to $2060 \mathrm{MPa}$ after upgrading to upper strength or after quenching [7].

It means, that the crankshaft must be made of at least steel of grade 12 or higher. This steel must be alloyed and heat-treated to meet the condition.

$$
\sigma_{\max }<\sigma_{D}, \quad \sigma_{D}=\frac{R_{e}}{k}
$$

Where $k=1,5$, is the safety factor.

\section{REFERENCES}

[1] Sandya, K., Keerthi, M., Srinivas, K. "Modeling and stress analysis of crankshaft using FEM package Ansys", International Research Journal of Engineering and Technology (IRJET) 3 (1), pp. 687 - 693, 2016.

[2] Milata, M., Musil, M. "Modelovanie budenia spal'ovacích motorov“, Strojárstvo/Strojírenství 6, pp. 134 - 137, 2019.

[3] Gouthami, P., Tulasi, S., Jadhao, S. M. "Dynamic Analysis of Crankcase and Crankshaft", International Engineering Research Journal, pp. 1531 - 1541, 2014.

[4] Úradníček, J., Musil, M., Bachratý, M. "Frequency response function measurement on simplified disc brake model“", Strojnícky časopis - Journal of Mechanical Engineering 68 (3), pp. 225 - 230, 2018. DOI: 10.2478/scjme-2018-0036

[5] Trebuňa, F., Bocko, J., Pástor, M., Lengvarský, P., Prada, E. “The finite element analysis of high precision positioning system", Strojnícky časopis - Journal of Mechanical Engineering 68 (4), pp. 41 - 48, 2018. DOI: 10.2478/scjme-2018-0045

[6] Šlesar, P., Jančo, R. "The calculation of the contact force and the contact width of shaft seals“, Strojnícky časopis - Journal of Mechanical Engineering 69 (1), pp. 123 - 130, 2019. DOI: $10.2478 /$ scjme-2019-0010

[7] Sejč, P., www.matnet.sav.sk. [Online] MatNet Slovakia, 2006, http://www.matnet.sav.sk/index.php?ID=159.

[8] Baran, P. "Vývoj a výskum dvojhmotového zotrvačníka“, Dizertačná práca, Technická univerzita v Košiciach, Košice, pp. 116 - 117, 2015. 
[9] Drápal, L., Novotný, P. "Torsional vibration analysis of crank train with low friction losses“, In JVE International ltd. Journal of vibroengineering 19 (8), pp. 5691 - 5701, 2017. DOI: $10.21595 /$ jve. 2017.17876

[10] Milata, M., Musil, M. "Návrh parametorv kyvadlového tlmiča na potláčanie torzného kmitania“, Strojárstvo/Strojírenství 5, pp. 76-77, 2020.

[11] Gend, M., Budak, B., Kaya, N. "Modelling and Vibration Analysis of Powertrain System“, In International Journal of automotive science and technology 2 (1), pp. 17 25, 2018. DOI: $10.30939 /$ ijastech..345094

[12] Žiaran, S. "Znižovanie kmitania a hluku v priemysle“, STU v Bratislave, Bratislava, 2006. ISBN 8022723665.

[13] Musil, M. "Pasívna a aktívna vibroizolácia strojov",Vydavatel'stvo STU, Bratislava, 2012. ISBN 978-80-227-3733-3

[14] Musil, M. “Základy dynamiky strojov s Matlabom“, STU v Bratislave, Bratislava, 2013. ISBN 97-880-2273-9382

[15] Šolek, P. “Technická mechanika 2“, STU v Bratislave, Bratislava, 2009. ISBN 9788022732062.

[16] Filipovic, I., Bibic, D., Milasinovic, A., Blazevic, A., Pecar, A. "Preliminary selection of basic parameters of different torsional vibration dampers intended for use in mediumspeed diesel engines“, Transactions of FAMENA 36 (3), pp. 79 - 88, 2012. 